GRASAS Y ACEITES 70 (2)

April-June 2019, e302

ISSN-L: 0017-3495

https://doi.org/10.3989/gya.0705182

\title{
Chia seed oil as an additive to yogurt
}

\author{
D. Derewiaka ${ }^{\mathrm{a}, \varpi}$, N. Stepnowska ${ }^{\mathrm{a}}$, J. Bryśs $^{\mathrm{b}}$, M. Ziarno ${ }^{\mathrm{a}}$, M. Ciecierska ${ }^{\mathrm{a}}$ and J. Kowalska ${ }^{\mathrm{a}}$ \\ Warsaw University of Life Sciences, Faculty of Food Sciences, \\ ${ }^{a}$ Department of Biotechnology, Microbiology and Food Evaluation \\ ${ }^{\mathrm{b}}$ Department of Chemistry \\ Corresponding author: dorota_derewiaka@sggw.pl
}

Submitted: 03 July 2018; Accepted: 09 October 2018. 18 February 2019

SUMMARY: The aim of this study was to evaluate the effect of a $2 \%$ chia seed oil addition to natural yogurt on its quality and to determine whether chia seed oil can be used as an additive in fermented milk products. The dominant species of microorganisms found in yogurt was Lb. delbruecki subsp. bulgaricus. The number in natural yogurt varied from 6.2 to $6.3 \cdot 10^{6} \mathrm{CFU} \cdot \mathrm{g}^{-1}$ and in enriched yogurt between 6.1 and $6.3 \cdot 10^{6} \mathrm{CFU} \cdot \mathrm{g}^{-1}$. Chia seed oil contained $4.5 \mathrm{~g}$ of sterol per $100 \mathrm{~g}$ of oil. The addition of $2 \%$ chia seed oil to natural yogurt resulted in a high content of phytosterol in yogurt. Natural yogurt contained $1.2 \mathrm{~g}$ of cholesterol in $100 \mathrm{~g}$ of the fat fraction of yogurt. Enriched yogurt contained $2 \mathrm{~g}$ of phytosterols. The addition of $2 \%$ chia seed oil to natural yogurt resulted in higher amounts of unsaturated fatty acids, especially linoleic and $\alpha$-linolenic acid.

KEYWORDS: Chia seeds; Enrichment; Yogurts

RESUMEN: El aceite de semilla de chía como aditivo para yogur. El objetivo del estudio fue evaluar el efecto de la adición del $2 \%$ de aceite de semilla de chía a yogures naturales sobre la calidad de los yogures y determinar si el aceite de semillas de chía se puede usar como aditivo en productos lácteos fermentados. La especie dominante de microorganismos que se encuentran en los yogures fue $L b$. delbruecki subsp. bulgaricus. Su número varió en yogures naturales entre $6,2-6,3 \cdot 10^{6} \mathrm{UFC} \cdot \mathrm{g}^{-1} \mathrm{y}$ en yogures enriquecidos $6,1-6,3 \cdot 10^{6} \mathrm{UFC} \cdot \mathrm{g}^{-1}$. El aceite de semilla de chía contenía $4,5 \mathrm{~g}$ de esteroles por $100 \mathrm{~g}$ de aceite. La adición de un $2 \%$ de aceite de semilla de chía al yogur natural dio como resultado un alto contenido de fitosteroles en el yogur. Los yogures naturales contenían 1,2 $\mathrm{g}$ de colesterol en $100 \mathrm{~g}$ de fracción de grasa de yogur, y los yogures enriquecidos contenían $2 \mathrm{~g}$ de fitosteroles. La adición del $2 \%$ de aceite de semilla de chía a los yogures naturales dio como resultado mayores cantidades de ácidos grasos insaturados, especialmente ácido linoleico y $\alpha$-linolénico.

PALABRAS CLAVE: Enriquecimiento; Semillas de chía; Yogures

ORCID ID: Derewiaka D https://orcid.org/0000-0002-2817-6513, Stepnowska N https://orcid.org/0000-0001-70466402, Bryś J https://orcid.org/0000-0002-7852-3624, Ziarno M https://orcid.org/0000-0001-7445-6375, Ciecierska M https://orcid.org/0000-0002-6076-5748, Kowalska J https://orcid.org/0000-0003-1723-5669

Citation/Cómo citar este artículo: Derewiaka D, Stepnowska N, Bryś J, Ziarno M, Ciecierska M, Kowalska J. 2019. Chia seed oil as an additive to yogurt. Grasas Aceites 70 (2), e302. https://doi.org/10.3989/gya.0705182

Copyright: (C2019 CSIC. This is an open-access article distributed under the terms of the Creative Commons Attribution 4.0 International (CC BY 4.0) License. 


\section{INTRODUCTION}

Recent years have seen an increased interest in fermented milk drinks, particular in yogurt-based formulations. More and more consumers are reaching for it in their daily diet, and their annual intake in the European Union ranges from $6.5-19 \mathrm{~kg}$ per person, with the largest share of yogurt containing fruit (Agriculture and Agri-Food Canada -Report 2015). However, an interest in natural yogurt is also growing year by year, which is seen as a healthier food, with a higher bioavailability of nutrients and minerals (Gahruie et al., 2015).

Yogurt is defined as a product resulting from milk by fermentation with a mixed starter culture consisting of Streptococcus thermophilus and Lactobacillus bacteria (Buttriss, 2003). The FAO/WHO definition is more specific because it further specifies that the microflora present in yogurt must remain live, active and contain a minimum of $10^{7}$ live bacteria in $1 \mathrm{~mL}$ or $\mathrm{g}$ until the last day of use. This product may contain additives e.g. fruits, vegetables or seeds, such as chia seeds.

Chia (Salvia hispanica L.) is a summer annual herbaceous plant belonging to the Labiatae Family. The species originated in mountainous areas extending from West Central Mexico to Northern Guatemala. Chia seeds require sub-tropical conditions for their growth. Chia seeds are a rich source of many beneficial ingredients. Their composition includes from $25 \%$ to $38 \%$ fats, most of which are polyunsaturated fatty acids. Chia is considered to be the plant with the highest known percentage of $\alpha$-linolenic acid $(\Omega-3)$. It accounts for nearly $68 \%$ of all fatty acids present in seeds. This is particularly beneficial for humans because the human body is unable to synthesize polyunsaturated fatty acids and therefore must be supplied by food (Kaur et al., 2014). An adequate intake of $\Omega-3$ fatty acids is crucial for visual function and neural development. An increased intake of the long-chain $\Omega-3$ fatty acids may be beneficial in a variety of psychiatric and neurological disorders, including neurodegenerative conditions. Moreover, $\Omega-3$ fatty acids are found to have neuroprotective potential in acute neurological injuries (Melgosa et al., 2019).

Chia seeds are also distinguished by a high content of vitamins $\mathrm{E}$ and minerals compared to other seeds. They contain a relatively high content of vitamin E, about $8 \mathrm{mg}$ per 100g (Silva da et al., 2017). Moreover, chia seeds are a precious source of calcium, magnesium, and potassium. The concentration of calcium in chia seeds is $4.2 \mathrm{~g}$ and magnesium is $4.9 \mathrm{~g}$. The content of potassium is $13.4 \mathrm{~g}$ per $100 \mathrm{~g}$ of seeds (Ding et al., 2018).

The most abundant polyphenols in chia seeds are phenolic acids, including rosmarinic, caffeic and ferulic acid (Rahman et al., 2017). Moreover flavonoids, condensed tannis, rutin, p-anisic acid, and hesperidin were found in chia seeds (Ding et al., 2018). Rosmarinic acid is known to have antiinflammatory, antiviral, antibacterial, and antimutagenic activity (Rahman et al., 2017). Caffeic acid is an organic compound belonging to the phenolic group of cinnamic acids. In the human body, it is responsible for the prevention of diabetes (by increasing the sensitivity of cells to insulin) or for reducing the risk of stomach cancer (Nadeem et al., 2017).

In 2009, the European Food Safety Authority published a positive decision about introducing chia seeds on the market. The decision permits adding $5 \%$ chia seed to bread products. Four years later the Commission Implementing Decisions recommended an extension of the use of chia seeds to no more than $10 \%$ in baked products, breakfast cereals, fruit, nut and seed mixes, and the marketing of pre-packed chia seeds. Moreover, food producers are obliged to inform consumers that the recommended daily intake of chia seeds is no more than $15 \mathrm{~g}$ per day. Still, chia seed addition to fermented milk products like yogurt and fermented milk products flavored with fruit components, fruit spread or cereal and/or pulse-based ready-to-serve (RTS) meals, and fruit preparations has not yet been approved. The application of 3\% chia seed in chocolate bars is currently pending by the EFSA [EU website].

The aim of this study was to investigate how the addition of $2 \%$ chia seed oil would affect the quality of natural yogurt. The article presents the changes in fatty acid and sterol compositions in the fat fraction of the analyzed yogurt and describes how the addition of chia seed oil to natural yogurt does not change the $\mathrm{pH}$ or LAB population over a 4-week storage period, or the sensory quality of natural yogurt. This article focuses on the addition of chia oil to natural yogurt in contrast to other articles, which mainly describe the addition of chia seeds to yogurt and their impact on product quality.

\section{MATERIALS AND METHODS}

\subsection{Chia seeds oil preparation}

Chia seeds were produced by the company My-Vita and purchased at the organic food store in Warsaw (Poland) in 2016. The oil extraction from chia seeds was carried out according to the recommendations of the manufacturer of the PITEBA oil press. The extraction efficiency of PITEBA oil expeller was $80 \%$, oil yield was $0.9 \mathrm{l} \cdot \mathrm{h}^{-1}$. Initially, the seeds were watered down with $50 \mathrm{~g}$ of water per kilogram. Water was added in small portions until the seeds became sticky, uniform, and formed a mucilage mass. The seeds were stored in a closed container at room temperature for $24 \mathrm{~h}$. After this time the seeds were transferred to the hand press. Then the wick 
was burned from the paraffin container to gently warm the beans inside the press. After $10 \mathrm{~min}$ the process started by turning the crank clockwise (the pressure exerted to extract the oil was unknown). The oil flowed through the outlet opening in the front bottom of the tube. The oil was collected in a $500 \mathrm{~mL}$ glass beaker and after cooling it was centrifuged at $10000 \mathrm{rpm}$ for $10 \mathrm{~min}$. Subsequently, the clear (top) oil was carefully collected over a nitrogen gas atmosphere, sealed and stored at a cooling temperature $\left(4^{\circ} \mathrm{C}\right)$.

\subsection{Preparation of yogurt}

$850 \mathrm{~g}$ of UHT milk with a $1.5 \%$ fat content of OSM Wart-Milk (Poland) were weighed into 6-sterilized 1-liter Schott bottles and then $17 \mathrm{~g}$ of skimmed powdered milk from S.M. Gostyń (Poland) were added. The whole mass was intensively mixed using a laboratory mechanical homogenizer (Silverson L4R, England) until the milk granules dissolved completely $\left(4000 \mathrm{rpm}\right.$ for $15 \mathrm{~min}$ at $\left.25^{\circ} \mathrm{C}\right) .2 \mathrm{~g}$ of chia seed oil were added to the batches of enriched yogurt to partially replace milk fat. The level of chia seed oil addition was earlier investigated and did not lead to de-lamination of the product. The whole mass was mixed once again $(4000 \mathrm{rpm}$ for $10 \mathrm{~min}$ at $25^{\circ} \mathrm{C}$ ) and incubated in a $50{ }^{\circ} \mathrm{C}$ water bath for 30 min, stirring occasionally.

After this time, $0.002 \%$ of yogurt starter cultures was added to all the bottles (YC-180 obtained from Chr. Hansen, Poland), followed by intensive stirring for $5 \mathrm{~min}$. The prepared product was then poured into $40 \mathrm{~mL}$ jars ( 5 jars from each bottle) and into the thermostat (temperature $45^{\circ} \mathrm{C}$ ) to form a curd yogurt. Incubation was carried out for $4 \mathrm{~h}$ until the yogurt curd was suitably formed, uniform and dense. The yogurt was then cooled and stored at refrigerated temperatures for 0,14 , and 28 days.

\subsection{Fat extraction procedure}

In order to extract the fat fraction required for the determination of fatty acids and sterols in yogurt, the samples were weighed into Falcon centrifuge tubes respectively:

- For determination of fatty acids: $1.5 \mathrm{~g}$ of enriched yogurt and $3 \mathrm{~g}$ of natural yogurt.

- For determination of sterols: $6 \mathrm{~g}$ of enriched yogurt and $12 \mathrm{~g}$ of natural yogurt.

Afterwards the mixture of chloroform: methanol $(2: 1, \mathrm{v}: \mathrm{v})$ was added to the enriched yogurt $(12 \mathrm{~mL})$ and to natural yogurt $(20 \mathrm{~mL})$. The samples were centrifuged at $9000 \mathrm{rpm}$ for $10 \mathrm{~min}$. The bottom chloroform layer was collected and filtered into the vials. The samples were evaporated under a nitrogen stream and weighed after complete drying.

\subsection{Determination of fatty acids}

The extracted fat samples were weighed (about $50 \mathrm{mg}$ ) and dissolved in $2 \mathrm{~mL}$ of hexane. Next, $0.5 \mathrm{~mL}$ of $2 \mathrm{M} \mathrm{KOH}$ in methanol was added to the samples, afterwards the samples were shaken and left to for $1 \mathrm{~h}$. After the process of transesterification $1 \mathrm{~mL}$ of the upper layer was collected carefully and transferred to a glass vial. The sample was evaporated in a stream of nitrogen and 0.5 $\mathrm{mL}$ hexane was added. Each fat sample was analyzed in triplicate. The separation of the fatty acid methyl esters was performed with the use of a gas chromatograph coupled with mass spectrometry Shimadzu - QP-2010S and capillary column ZB FFAP Phenomenex $(30 \mathrm{~m} \times 0.25 \mathrm{~mm} \times 0.25 \mu \mathrm{m})$. Column temperature procedure: initial $60{ }^{\circ} \mathrm{C}$ for $3 \mathrm{~min}$, temperature rise at $4{ }^{\circ} \mathrm{C} \cdot \mathrm{min}^{-1}$ to $230^{\circ} \mathrm{C}$ and held for $5 \mathrm{~min}$. Injector and ion source temperature were as follows: $230^{\circ} \mathrm{C}$ and $240{ }^{\circ} \mathrm{C}$. The carrier gas was helium, with a flow of $1.14 \mathrm{~mL} \cdot \mathrm{min}^{-1}$. The interface temperature of GC-MS was $225^{\circ} \mathrm{C}$. The ionization energy was $70 \mathrm{eV}$. The Total Ion Monitoring (TIC) was used to detect fatty methyl esters $(\mathrm{m} / \mathrm{z}$ ranged $50-500)$. The qualitative analysis of the fatty acid methyl esters was made on the basis of a comparison of their retention times with those of available standards and mass spectra as well as literature data. The results were presented as percentage of each fatty acid in the total profile of fatty acids. Each sample was analyzed in triplicate.

\subsection{Determination of sterols}

The extracted fat samples were weighed (about $150 \mathrm{mg}$ ) and dissolved in $2 \mathrm{~mL}$ of hexane. Than $100 \mu \mathrm{L}$ of $5 \alpha$-Cholestan-3 $\beta$-ol standard (concentration $11.93 \mathrm{mg}$ in $25 \mathrm{~mL}$ of chloroform) were added to the samples. Next $0.5 \mathrm{~mL}$ of $2 \mathrm{M} \mathrm{KOH}$ in methanol was added to the samples; afterwards the samples were shaken and left for $1 \mathrm{~h}$. After the process of transesterification $1 \mathrm{~mL}$ of the upper layer was collected carefully and transferred to a glass vial. The sample was evaporated in a stream of nitrogen and $100 \mu \mathrm{L}$ of silylating reagent (BSTFA + TMCS, 99:1) and $100 \mu \mathrm{L}$ pyridine were added. The prepared sample was shaken and left for $24 \mathrm{~h}$ at room temperature according to the derivatization process. Next 0.5 $\mathrm{mL}$ of hexane was added and the trimethylether sterol content was analyzed. The separation of sterol derivatives was performed with the use of GC coupled with a Shimadzu - QP-2010S and capillary column ZB 5MS Phenomenex (30 m x $0.25 \mathrm{~mm} \times 0.25 \mu \mathrm{m})$. Column temperature procedure: initial $60^{\circ} \mathrm{C}$ for $3 \mathrm{~min}$, temperature rate $15{ }^{\circ} \mathrm{C} \cdot \mathrm{min}^{-1}$ to $250{ }^{\circ} \mathrm{C}$, second temperature rate $3{ }^{\circ} \mathrm{C} \cdot \mathrm{min}^{-1}$ to $310{ }^{\circ} \mathrm{C}$ and held for $10 \mathrm{~min}$. The 
injector and ion source temperature were 250 ${ }^{\circ} \mathrm{C}$ and $240{ }^{\circ} \mathrm{C}$, respectively. The carrier gas was helium at a flow of $0.47 \mathrm{~mL} \cdot \mathrm{min}^{-1}$. The interface temperature of the GC-MS was $250{ }^{\circ} \mathrm{C}$. The ionization energy was $70 \mathrm{eV}$. The Total Ion Monitoring (TIC) was used to detect sterols ( $\mathrm{m} / \mathrm{z}$ ranged 100-600). The qualitative analysis of trimethylesters was made on the basis of a comparison of their retention times with the retention time of available standards and mass spectra as well as literature data. The internal standard $5 \alpha$-Cholestan-3 $\beta$-ol was used to quantify sterols and the results were presented in $\mathrm{mg} \cdot 100 \mathrm{~g}^{-1}$ of fat. Each sample was analyzed in triplicate.

\subsection{Determination of $\mathrm{LAB}$ population}

Preparations of samples for microbiological analysis, as well as dilutions, were performed according to ISO 6887-5:2010. MRS agar (Merck, Poland) was used to quantify $L b$. delbrueckii subsp. bulgaricus and M-17 agar (Merck, Poland) was used to quantify Streptococcus thermophilus. Plates of M17 agar and MRS agar inoculated with sample dilutions were incubated at $37^{\circ} \mathrm{C}$ for $72 \mathrm{~h}$ in aerobic and anaerobic conditions (Anaerocult A, Merck, Poland), respectively. After incubation, the number of bacteria cells was converted to colony-forming units in $1 \mathrm{~mL}\left(\mathrm{CFU} \cdot \mathrm{mL}^{-1}\right)$. Each sample was analyzed in triplicate.

\section{7. pH measurements}

The $\mathrm{pH}$ measurements in the yogurt samples after fermentation and storage $(7,14,21$, and 28 days) ware determined with the use of a $\mathrm{pH}$ meter HI 931400 Microprocessor pH-metr (HANNA Instruments company). All experiments were repeated three times.

\subsection{Sensory evaluation}

The yogurt samples were subjected to a sensory evaluation by 15 panelists. The samples were evaluated after $24 \mathrm{~h}$ of fermentation and storage at $4{ }^{\circ} \mathrm{C}$ for 14 and 28 days. Each panelist was trained and asked to rank all samples for color, surface gloss, flavor, fatty flavor, taste, fatty taste, uniformity of structure, texture, foreign tastes, acidity and acceptance using a 5-point hedonic scale, ranging from 1 (spoiled food sample) to 5 (the best feature, meeting the sensory requirements). The yogurt samples were coded, and samples were given to the panelists in an anonymous and random manner.

\subsection{Statistical analysis}

The results were analyzed statistically using the Excel and Statistica 12 programme, where a one way Anova variance analysis was performed (Tukey's post-hoc score) (student grouped medium).

\section{RESULTS AND DISCUSSION}

\subsection{Fatty acids content in chia seed oil}

Chia seed oil contained five different fatty acids (Table 1). The most abundant fatty acid was $\alpha$-linolenic acid (66.1-66.8\%). Another polyunsaturated fatty acid was linoleic acid (17.0-17.2\%). The content of oleic acid was only $6.66 \%$. In the group of saturated fatty acids palmitic (6.4-6.6\%) and stearic fatty acids $(3.1-3.2 \%)$ were determined. Total content of unsaturated fatty acids was very high at $90.2 \%$, and $83.5 \%$ of these were polyunsaturated fatty acids. The proportion of $\Omega-6$ to $\Omega-3$ fatty acids in the chia seed oil was favorable with the amount average 0.26 and fulfilled the nutritional recommendation set by the European Union.

TABLE 1. The profile of fatty acids in chia seed oil $(n=3$, mean \pm SD)

\begin{tabular}{|c|c|c|c|}
\hline Fatty acids & & Profile $(\%)$ & Results reported by other authors (\%) \\
\hline Saturated & & $9.69 \pm 0.12$ & \\
\hline Palmitic acid & $\mathrm{C} 16: 0$ & $6.52 \pm 0.08$ & 7.47\% (Segura-Campos et al., 2014) \\
\hline Stearic acid & $\mathrm{C} 18: 0$ & $3.17 \pm 0.05$ & 0.3\% (Segura-Campos et al., 2014) \\
\hline Unsaturated, contc & ning: & $90.3 \pm 0.12$ & $90.3 \%$ (Coelho and Salas-Mellado, 2014) 90.9\% (Rossi et al., 2013) \\
\hline Monounsaturated & & $6.66 \pm 0.08$ & \\
\hline Oleic acid & $\mathrm{C} 18: 1$ cis 9 & $6.66 \pm 0.08$ & $7.2 \%$ (Ayerza and Coates, 2011$)$ \\
\hline Polyunsaturated & & $83.6 \pm 0.19$ & 79.5\% (Coelho and Salas-Mellado, 2014) \\
\hline Linoleic acid & $\mathrm{C} 18: 2$, cis 9, cis 12 & $17.10 \pm 0.09$ & $\begin{array}{l}(18.8-20.4 \%)(\text { Rossi et al., 2013, Ayerza and Coates 2011, Segura- } \\
\text { Campos et al., 2004) }\end{array}$ \\
\hline$\alpha$-linolenic acid & $\mathrm{C} 18: 3$, cis 9 , cis 12 , cis 15 & $66.54 \pm 0.28$ & $\begin{array}{l}(62.0-68.5 \%)(\text { Rossi et al., 2013, Ayerza and Coates 2011, Segura- } \\
\text { Campos et al., 2004) }\end{array}$ \\
\hline
\end{tabular}


The results published by Ayerza and Coates (2011) are very similar to ours, the percentage of palmitic acid was in the range of $6.4-7.7 \%$ and stearic 2.4-3.7\%. However, Ayerza, and Coates (2011) emphasized that the region of origin, methods of harvesting and storage of seeds had a strong influence on the content of these fatty acids. Moreover, the differences in extraction methods and their parameters may contradict to divergences in those results.

The same amount $(90.3 \%)$ of unsaturated fatty acids in chia seed oil was detected by Coelho and Salas-Mellado (2014). They confirmed that $79.5 \%$ of fatty acids were polyunsaturated and the most abundant were $\alpha$-linolenic, linoleic and oleic fatty acids.

Rossi et al., (2013) also showed that the unsaturated fatty acid content in chia seed oil was nearly $90.9 \%$. The approximate content of linoleic acid $(18.8-20.4 \%)$ and $\alpha$-linolenic $(62.0-68.5 \%)$ were also identified by other authors (Rossi et al., 2013, Ayerza and Coates, 2011, Segura-Campos et al., 2004).

Ayeza and Coates (2011) investigated the effect of feeding hens with different seeds on the contents of $\Omega-3$ acids in their eggs. These studies showed that hens fed with chia seeds showed the highest content of polyunsaturated fatty acids compared to hens fed with rapeseeds or linseed. Also, Fernandez et al., (2008) examined the effect of adding chia seeds to rats' feeding regime on blood plasma. The results showed that the levels of triglycerides and LDL lipoproteins in plasma decreased, and HDL lipoproteins and polyunsaturated $\omega-3$ acids were elevated. In addition, no side effects were observed in relation to the thymus or stomach of the rats. Thus, the use of chia seed and oil for the enrichment of food can lead to positive results. In particular, these products may exhibit equally beneficial effects on the human body as observed in laboratory animals.

\subsection{Fatty acids content in natural yogurt}

The most abundant fatty acid in the profile of yogurt was palmitic acid. In the group of saturated fatty acids stearic and lauric acid were present in high amounts (about $11.6 \%$ and $10.42 \%$, respectively) (Table 2). The second most abundant fatty acid in the total profile of fatty acids in natural yogurt was oleic acid $(25.27 \%)$, which is one of the monounsaturated fatty acids.

The saturated fatty acid composition was dominant in the fatty acid profile of yogurt $(65.60 \%$ on the day of manufacture, $67.54 \%$ after 14 days of storage and $66.18 \%$ after 28 days of storage). Unsaturated acids accounted for about $30 \%$ of the total profile, of which only $2.5-3.3 \%$ were polyunsaturated acids (linoleic acid and $\alpha$-linolenic) (Table 2). The content of unsaturated acids was slightly reduced and did

TABLE 2. The profile of fatty acids in natural yogurt $(n=3$, mean \pm SD)

\begin{tabular}{|c|c|c|c|c|}
\hline \multirow{3}{*}{ Fatty acid } & & \multicolumn{3}{|c|}{ Profile [\%] } \\
\hline & & \multicolumn{3}{|c|}{ Storage day } \\
\hline & & $\mathbf{0}$ & 14 & 28 \\
\hline \multicolumn{2}{|l|}{ Saturated } & $65.59 \pm 0.17^{\mathrm{a}}$ & $67.54 \pm 2.46^{\mathrm{a}}$ & $66.18 \pm 1.78^{a}$ \\
\hline Butyric acid & $\mathrm{C} 4: 0$ & $0.47 \pm 0.17^{\mathrm{a}}$ & $0.49 \pm 0.21^{\mathrm{a}}$ & $0.45 \pm 0.28^{\mathrm{a}}$ \\
\hline Caprylic acid & C6:0 & $1.76 \pm 0.09^{\mathrm{a}}$ & $1.94 \pm 0.22^{\mathrm{a}}$ & $1.74 \pm 0.21^{\mathrm{a}}$ \\
\hline Capric acid & $\mathrm{C} 8: 0$ & $2.99 \pm 0.54^{\mathrm{a}}$ & $3.18 \pm 0.72^{\mathrm{a}}$ & $2.94 \pm 0.26^{\mathrm{a}}$ \\
\hline Lauric acid & $\mathrm{C} 10: 0$ & $10.42 \pm 1.94^{\mathrm{a}}$ & $11.65 \pm 0.99^{\mathrm{a}}$ & $11.30 \pm 0.37^{\mathrm{a}}$ \\
\hline Myristic & $\mathrm{C} 12: 0$ & $0.99 \pm 0.04^{\mathrm{a}}$ & $0.98 \pm 0.04^{\mathrm{a}}$ & $0.97 \pm 0.02^{\mathrm{a}}$ \\
\hline Palimc acid & $\mathrm{C} 16: 0$ & $37.26 \pm 0.90^{\mathrm{a}}$ & $37.85 \pm 1.07^{\mathrm{a}}$ & $37.53 \pm 0.78^{a}$ \\
\hline Margaric acid & $\mathrm{C} 17: 0$ & $0.55 \pm 0.03^{\mathrm{a}}$ & $0.51 \pm 0.05^{\mathrm{ab}}$ & $0.51 \pm 0.06^{\mathrm{b}}$ \\
\hline Stearic acid & $\mathrm{C} 18: 0$ & $11.62 \pm 1.17^{\mathrm{a}}$ & $11.06 \pm 0.19^{\mathrm{a}}$ & $11.37 \pm 0.19^{\mathrm{a}}$ \\
\hline \multicolumn{2}{|c|}{ Unsaturated, containing: } & $31.45 \pm 1.40^{\mathrm{a}}$ & $30.25 \pm 1.38^{\mathrm{a}}$ & $30.41 \pm 0.78^{\mathrm{a}}$ \\
\hline \multicolumn{2}{|c|}{ Monounsaturated } & $28.18 \pm 1.91^{\mathrm{a}}$ & $27.79 \pm 1.42^{\mathrm{a}}$ & $27.81 \pm 1.05^{\mathrm{a}}$ \\
\hline Pentadecanoic acid & $\mathrm{C} 15: 1$, cis 7 & $1.22 \pm 0.03^{\mathrm{a}}$ & $1.22 \pm 0.12^{\mathrm{a}}$ & $1.17 \pm 0.06^{\mathrm{a}}$ \\
\hline Palmitoleic acid & $\mathrm{C} 16: 1$, cis 8 & $1.84 \pm 0.52^{\mathrm{a}}$ & $1.89 \pm 0.08^{\mathrm{a}}$ & $1.96 \pm 0.21^{\mathrm{a}}$ \\
\hline Oleic acid & $\mathrm{C} 18: 1$, cis 9 & $25.27 \pm 1.06^{\mathrm{a}}$ & $24.68 \pm 1.43^{\mathrm{a}}$ & $25.52 \pm 0.97^{\mathrm{a}}$ \\
\hline \multicolumn{2}{|l|}{ Polyunsaturated } & $3.28 \pm 1.11^{\mathrm{a}}$ & $2.47 \pm 0.41^{\mathrm{a}}$ & $2.59 \pm 0.53^{\mathrm{a}}$ \\
\hline Linoleic acid & $\mathrm{C} 18: 2$ cis 9, cis 12 & $2.34 \pm 1.13^{\mathrm{a}}$ & $1.95 \pm 0.49^{\mathrm{a}}$ & $1.83 \pm 0.16^{\mathrm{a}}$ \\
\hline$\alpha$-linolenic acid & $\mathrm{C} 18: 3$ cis 9, cis 12, cis 15 & $1.08 \pm 0.63^{\mathrm{a}}$ & $0.59 \pm 0.24^{\mathrm{a}}$ & $0.76 \pm 0.41^{\mathrm{a}}$ \\
\hline
\end{tabular}

a-c Different superscripts within a row show significant differences during storage $(\mathrm{P}<0.05)$ (according to one way ANOVA and Tukey test) 
not show statistical differences during 28 days of storage. According to many authors, the decrease in unsaturated fatty acids is due to the oxidative changes during the storage of these products under refrigerated conditions (Florence et al., 2012).

Paszczyk et al., (2006) also reported the composition of fatty acids of natural yogurt produced in a pilot-scale investigation. They confirmed that the most abundant fatty acids in natural yogurt were saturated fatty acids, including C16:0 (34.5\%); C10:0 (3.4\%); C18:0 (8.9\%). Regarding fatty acids, however, it must be emphasized that the composition of milk fat (the primary component of yogurt) is dependent on the cows' breeding conditions and the milking methods.

\subsection{Fatty acid contents in yogurt with the addition $2 \%$ of chia seed oil}

The highest amount in the fat fraction of yogurt with $2 \%$ chia seed oil was $\alpha$-linolenic acid $(45.33 \%)$ and it was the predominant component of the polyunsaturated fatty acid group. In the PUFA group the content of linoleic fatty acids was very high $12.93 \%$. Among the monounsaturated fatty acids the most abundant was oleic acid with the content of $12.41 \%$. In the group of saturated fatty acids, palmitic acid was predominant $(16.53 \%)$, followed by stearic acid $(5.79 \%)$ and lauric acid $(3.46 \%)$ (Table 3).
During 28 days of storage, the yogurt with the $2 \%$ addition of chia seed oil showed a reduced content of unsaturated fatty acids. On the first day of storage the total content of unsaturated fatty acids was $71.4 \%$, after two weeks of storage it was significantly lowered to $64.3 \%$, and after a moth of storage the content was only $63.6 \%$ (Table 3 ). More diversity was evident in the group of monounsaturated and polyunsaturated fatty acids, where polyunsaturated fatty acids predominated, and their percentage of total fatty acids during storage gradually decreased $(58.3 \%$ on the day of manufacture, $49.8 \%$ after 14 days and $47.9 \%$ after 28 days of storage). For both linoleic and $\alpha$-linolenic acid, significant statistical differences occurred between 14 and 28 days after production. This was probably due to oxidative fatty acid changes during storage. Cichosz and Czeczot (2011) emphasized that the rate of oxidative changes depends on the degree of saturation of the fatty acids present in the oil and on its content in the product. Polyunsaturated acids are therefore more susceptible to oxidation than unsaturated ones due to the presence of more unsaturated bonds that oxidize in contact with oxygen and are oxidized first. The content of monounsaturated fatty acids slightly increased during storage, which on the day of manufacture accounted for $13.1 \%$, after 14 days $14.5 \%$ and after 28 days $15.7 \%$.

Worth mentioning is the fact that ratio of $\omega 6: \omega 3$ fatty acids in enriched yogurt ranged from

TABLE 3. The profile of fatty acids in natural yogurt with addition of $2 \%$ chia seed oil ( $n=3$, mean \pm SD)

\begin{tabular}{|c|c|c|c|c|}
\hline \multirow{3}{*}{ Fatty acid } & & \multicolumn{3}{|c|}{ Profile [\%] } \\
\hline & & \multicolumn{3}{|c|}{ Storage day } \\
\hline & & $\mathbf{0}$ & 14 & 28 \\
\hline \multicolumn{2}{|l|}{ Saturated } & $28.16 \pm 2.24^{\mathrm{a}}$ & $34.53 \pm 2.55^{\mathrm{b}}$ & $34.73 \pm 2.82^{b}$ \\
\hline Butyric acid & $\mathrm{C} 4: 0$ & $0.19 \pm 0.05^{\mathrm{a}}$ & $0.23 \pm 0.13^{\mathrm{a}}$ & $0.20 \pm 0.11^{\mathrm{a}}$ \\
\hline Caprylic acid & C6:0 & $0.55 \pm 0.14^{\mathrm{a}}$ & $0.67 \pm 0.15^{\mathrm{a}}$ & $0.70 \pm 0.15^{\mathrm{a}}$ \\
\hline Capric acid & $\mathrm{C} 8: 0$ & $0.81 \pm 0.16^{\mathrm{a}}$ & $1.21 \pm 0.21^{\mathrm{b}}$ & $1.09 \pm 0.15^{\mathrm{b}}$ \\
\hline Lauric acid & $\mathrm{C} 10: 0$ & $3.46 \pm 0.43^{\mathrm{a}}$ & $4.72 \pm 0.42^{\mathrm{b}}$ & $4.72 \pm 0.50^{\mathrm{b}}$ \\
\hline Myristic & $\mathrm{C} 12: 0$ & $0.28 \pm 0.03^{\mathrm{a}}$ & $0.37 \pm 0.11^{\mathrm{b}}$ & $0.39 \pm 0.03^{\mathrm{b}}$ \\
\hline Palimc acid & $\mathrm{C} 16: 0$ & $16.53 \pm 1.18^{\mathrm{a}}$ & $20.06 \pm 1.21^{\mathrm{b}}$ & $19.85 \pm 1.45^{\mathrm{b}}$ \\
\hline Margaric acid & $\mathrm{C} 17: 0$ & $0.27 \pm 0.02^{\mathrm{a}}$ & $0.33 \pm 0.03^{\mathrm{b}}$ & $0.33 \pm 0.03^{\mathrm{b}}$ \\
\hline Stearic acid & $\mathrm{C} 18: 0$ & $5.79 \pm 0.32^{\mathrm{a}}$ & $6.75 \pm 0.47^{\mathrm{b}}$ & $6.94 \pm 0.62^{\mathrm{b}}$ \\
\hline \multicolumn{2}{|c|}{ Unsaturated, containing: } & $71.35 \pm 2.43^{\mathrm{a}}$ & $64.28 \pm 2.28^{\mathrm{b}}$ & $63.59 \pm 2.63^{\mathrm{b}}$ \\
\hline \multicolumn{2}{|c|}{ Monounsaturated } & $13.09 \pm 0.80^{\mathrm{a}}$ & $14.53 \pm 1.41^{\mathrm{ab}}$ & $15.70 \pm 1.85^{\mathrm{b}}$ \\
\hline Pentadecanoic acid & C15:1 & $0.40 \pm 0.06^{\mathrm{a}}$ & $0.53 \pm 0.06^{\mathrm{b}}$ & $0.52 \pm 0.40^{\mathrm{b}}$ \\
\hline Palmitoleic acid & $\mathrm{C} 16: 1$ cis 9 & $0.68 \pm 0.09^{\mathrm{a}}$ & $0.87 \pm 0.15^{\mathrm{b}}$ & $0.91 \pm 0.13^{\mathrm{b}}$ \\
\hline Oleic acid & $\mathrm{C} 18: 1$ cis 9 & $12.41 \pm 0.74^{\mathrm{a}}$ & $13.66 \pm 1.27^{\mathrm{ab}}$ & $14.79 \pm 1.78^{\mathrm{b}}$ \\
\hline \multicolumn{2}{|l|}{ Polyunsaturated } & $58.27 \pm 3.05^{\mathrm{a}}$ & $49.75 \pm 2.52^{\mathrm{b}}$ & $47.89 \pm 4.13^{\mathrm{b}}$ \\
\hline Linoleic acid & $\mathrm{C} 18: 2$ cis 9,12 & $12.93 \pm 0.44^{\mathrm{a}}$ & $11.53 \pm 0.49^{\mathrm{a}}$ & $11.29 \pm 0.79^{b}$ \\
\hline$\alpha$-linolenic acid & $\mathrm{C} 18: 312,15$ cis $6,9,12$ & $45.33 \pm 2.63^{\mathrm{a}}$ & $38.22 \pm 2.06^{\mathrm{a}}$ & $36.59 \pm 3.35^{\mathrm{b}}$ \\
\hline
\end{tabular}

a-c Different superscripts within a row show significant differences during storage $(\mathrm{P}<0.05)$ (according to one way ANOVA and Tukey test) 
0.28-0.31, which is within the EU recommendations of 0.25-1.00. In the average European diet the proportion of $\omega 6: \omega 3$ acids is on average 20:1, thus causing a high risk for cardiovascular diseases and cancers. The same observations were mentioned by Kargulewicz et al., (2016), who stated that chia seed fat fraction and the proportion of $\omega 6: \omega 3$ fatty acids was in the EU's recommendations and accounted for 0.29 .

\subsection{Sterol contents in chia seed oil}

Four different sterols were determined in chia seed oil and the total content of sterols was $4.56 \mathrm{~g}$ per $100 \mathrm{~g}$ of oil (Table 4). The sterol fraction consists of $79.8 \%$ of $\beta$-sitosterol. A lower percentage in the phytosterol profile was noted for campesterol, $5 \Delta$-avenasterol and stigmasterol and they accounted for $12.3 \%, 4.4 \%$ and $3.95 \%$, respectively. AlvarezChavez et al., (2008) showed that the total content of sterols in the oil extracted from chia seeds may vary depending on the region of cultivation and the color of the seeds from 4.0 to $12.6 \mathrm{~g}$ per $100 \mathrm{~g}$ of oil for black seeds.

In mixtures of seeds available on the market the average content of phytosterols ranged from 4.4-5.0 g per $100 \mathrm{~g}$ of oil. Alvarez-Chavez et al., (2008) reported that the highest amount in chia

TABLE 4. Sterol contents $\left(\mathrm{mg} \cdot 100 \mathrm{~g}^{-1}\right.$ of oil) in chia seed oil $(n=3$, mean \pm SD)

\begin{tabular}{lll}
\hline Sterol & $\begin{array}{l}\mathbf{g} \cdot \mathbf{1 0 0 g}^{-1} \\
\text { of oil }\end{array}$ & $\begin{array}{l}\text { Results reported by other } \\
\text { authors } \mathbf{~} \cdot \mathbf{1 0 0 g}^{-1} \text { of oil }\end{array}$ \\
\hline $\begin{array}{l}\text { Campesterol } \\
\text { Stigmasterol }\end{array}$ & $0.54 \pm 0.08^{\mathrm{c}}$ & \\
$\beta$-sitosterol & $3.18 \pm 0.02^{\mathrm{d}} \pm 0.01^{\mathrm{b}}$ & $\begin{array}{l}3.5-6.0 \text { Alvarez-Chavez } \text { et } \text { al. }, \\
(2008)\end{array}$ \\
& & \\
$5 \Delta$-avenasterol & $0.20 \pm 0.01^{\mathrm{d}}$ & \\
Total sterols & $4.56 \pm 0.01^{\mathrm{a}}$ & $\begin{array}{l}4.4-5.0 \text { Alvarez-Chavez et al. }, \\
(2008)\end{array}$ \\
\hline
\end{tabular}

a-c Different superscripts within a column show significant differences $(\mathrm{P}<0.05)$ (according to one way ANOVA and Tukey test)

TABLE 5. Sterol contents in natural yogurt $\left(\mathrm{g} \cdot 100 \mathrm{~g}^{-1}\right.$ of extracted fat $)(n=3$, mean \pm SD)

\begin{tabular}{|c|c|c|c|}
\hline \multirow[b]{3}{*}{ Sterol } & \multicolumn{3}{|c|}{$\mathrm{g} \cdot 100 \mathrm{~g}^{-1}$ of extracted fat } \\
\hline & \multicolumn{3}{|c|}{ Storage day } \\
\hline & 0 & 14 & 28 \\
\hline Cholesterol & $1.20 \pm 0.05^{\mathrm{a}}$ & $1.20 \pm 0.07^{\mathrm{ab}}$ & $1.06 \pm 0.03^{\mathrm{b}}$ \\
\hline $5 \Delta$-avenasterol & $0.06 \pm 0.01^{\mathrm{a}}$ & $0.12 \pm 0.03^{\mathrm{a}}$ & $0.15 \pm 0.03^{\mathrm{a}}$ \\
\hline Total sterol & $1.23 \pm 0.05^{\mathrm{a}}$ & $1.32 \pm 0.07^{\mathrm{a}}$ & $1.21 \pm 0.05^{\mathrm{a}}$ \\
\hline
\end{tabular}

a-c Different superscripts within a row show significant differences during storage $(\mathrm{p}<0.05)$ (according to one way ANOVA and Tukey test) seed oil was $\beta$-sitosterol, with an average amount which oscillated in the range of about 3.5-6.0 $\mathrm{g} \cdot 100 \mathrm{~g}^{-1}$ of oil.

\subsection{Sterol content in natural yogurt}

In the natural yogurt only two sterols (cholesterol and 5 $\Delta$-avenasterol) were identified (Table 5). In the fat fraction extracted from yogurt the total sterol content was $1.23 \mathrm{~g} \cdot 100 \mathrm{~g}^{-1}$ of oil on the day of production. After 28 day of storage the total content of sterol had not changed, but the cholesterol content was significantly lowered from $1.2 \mathrm{~g}$ to $1.06 \mathrm{~g}$ of cholesterol $100 \mathrm{~g}^{-1}$ of fat. Cholesterol is a typical sterol present milk fat. The cholesterol content in yogurt may vary, because it is influenced by the fat contents in yogurt and milk, thermal processing, homogenization, and the type of starter culture used (Kovacs et al., 2004).

Talpur et al., (2008) showed that yogurt with high amounts of fat contained from 0.11 to 0.14 $\mathrm{g} \cdot 100 \mathrm{~g}^{-1}$ of fat. Moreover, Kovacs et al., (2004) pointed out that low-fat yogurts were characterized by a high concentration of cholesterol at about $1.00 \mathrm{~g} \cdot 100 \mathrm{~g} \mathrm{~g}^{-1}$ of fat, due to small fat globules in the structure, but with a large tangential surface where cholesterol was accumulated. Grega et al., (2000) emphasized that the amount of cholesterol in a milk product is influenced by the heat treatment of the milk. Milk sterilized at high temperatures (UHT milk - ultra high temperature) uses high amounts of cholesterol (average $0.36 \mathrm{~g} \cdot 100 \mathrm{~g}^{-1}$ of fat), compared to pasteurized milk $\left(0.24 \mathrm{~g} \cdot 100 \mathrm{~g}^{-1}\right.$ of fat). Lee et al., (2011) found that the decrease in cholesterol in yogurt could be due to enzymes produced by some microorganisms that have the ability to break down cholesterol, such as cholesterol reductase and cholesterol oxidase.

TABLE 6. Sterol contents in yogurt enriched in $2 \%$ chia seed oil $\left(\mathrm{g} \cdot 100 \mathrm{~g}^{-1}\right.$ of extracted fat $)(\mathrm{n}=3$, mean $\pm \mathrm{SD})$

\begin{tabular}{|c|c|c|c|}
\hline \multirow[b]{3}{*}{ Sterol } & \multicolumn{3}{|c|}{$\mathrm{g} \cdot 100 \mathrm{~g}^{-1}$ of extracted fat } \\
\hline & \multicolumn{3}{|c|}{ Storage day } \\
\hline & 0 & 14 & 28 \\
\hline Cholesterol & $1.26 \pm 0.24^{\mathrm{a}}$ & $1.20 \pm 0.20^{\mathrm{a}}$ & $1.16 \pm 0.24^{\mathrm{a}}$ \\
\hline Campesterol & $0.25 \pm 0.04^{\mathrm{a}}$ & $0.25 \pm 0.03^{\mathrm{a}}$ & $0.17 \pm 0.08^{\mathrm{a}}$ \\
\hline Stigmasterol & $0.09 \pm 0.04^{\mathrm{a}}$ & $0.10 \pm 0.03^{\mathrm{a}}$ & $0.07 \pm 0.03^{\mathrm{a}}$ \\
\hline$\beta$-sitosterol & $1.66 \pm 0.26^{\mathrm{a}}$ & $1.59 \pm 0.33^{\mathrm{a}}$ & $0.96 \pm 0.36^{\mathrm{a}}$ \\
\hline $5 \Delta$-avenasterol & $0.08 \pm 0.04^{\mathrm{a}}$ & $0.06 \pm 0.02^{\mathrm{a}}$ & $0.07 \pm 0.06^{\mathrm{a}}$ \\
\hline Total sterol & $3.34 \pm 0.07^{\mathrm{a}}$ & $3.20 \pm 0.19^{\mathrm{a}}$ & $2.84 \pm 0.09^{\mathrm{b}}$ \\
\hline
\end{tabular}

a-c Different superscripts within a row show significant differences during storage $(\mathrm{P}<0.05)$ (according to one way ANOVA and Tukey test) 


\subsection{Sterol content in yogurt with the $2 \%$ addition of chia seed oil}

In the fat fraction of enriched yogurt, 5 different sterols were detected (Table 6). The total content of sterols in the enriched yogurt decreased after 28 days of storage. On the first day of storage the total amount of sterols was $3.34 \mathrm{~g} \cdot 100 \mathrm{~g}^{-1}$ of extracted oil, after 14 days of storage it was 3.2 and after 28 days it was $2.84 \mathrm{~g} \cdot 100 \mathrm{~g}^{-1}$ of oil. In the sterol fraction only cholesterol was detected among animal sterols, which is a characteristic for dairy products. The most abundant plant sterols determined in the yogurt was $\beta$-sitosterol, which accounted about $50 \%$ of the sterol fraction in fresh yogurt and after storage for 14 days. After 28 days of storage its content was decreased by about $10 \%$, but this change was not statistically significant. In the phytosterol group, campesterol, stigmasterol, and $5 \Delta$-avenasterol were also observed. The same as with the $\beta$-sitosterol content, the concentration of campesterol was lowered after 28 days of storage from 0.25 to $0.18 \mathrm{~g} \cdot 100$ $\mathrm{g}^{-1}$ of oil. The remaining phytosterols - stigmasterol and $5 \Delta$-avenasterol were present in significantly lower amounts at $0.06-0.1 \mathrm{~g} \cdot 100 \mathrm{~g}^{-1}$ of extracted oil. Rudzińska et al., (2014) observed the concentration of phytosterols during storage of enriched margarines. The authors reported that the losses in phytosterol concentrations in the margarines were as follows: $4 \%$ after 4 weeks, $10 \%$ after 8 weeks and $21 \%$ after 12 weeks of storage at $4{ }^{\circ} \mathrm{C}$. The higher storage temperature $\left(20{ }^{\circ} \mathrm{C}\right)$ led to greater losses in phytosterols, which reached $9 \%, 26 \%$ and $33 \%$ after 4,8 and 12 weeks of storage, respectively (Rudzińska et al., 2014). The authors indicated that the degradation of phytosterols relies on the oxidative degradation process. The mechanism usually follows a free radical, which can initiate and stimulate the oxidation of sterols (Rudzińska et al., 2014). Gawrysiak-Witulska et al., (2012) also described the changes in the rapeseed phytosterol fraction during storage. The phytosterol losses after 18 days of seed storage at a temperature of 25 and $30^{\circ} \mathrm{C}$ reached 11 and $13 \%$ in seeds with moisture contents of 10,12 and $16 \%$ in seeds with a moisture content of $12.5 \%$, while they were 24 and $58 \%$ in seeds with a moisture content of $15.5 \%$. On the other hand, Nieminen et al., (2016) reported that the phytosterols present in biscuits which were stored for 74 weeks at room temperature were stable and no decrease in plant stanol content was recorded.

The results of the study described in this paper are difficult to discuss because there is no information on the effect of enriching yogurt with chia seed oils rich in phytosterols in the literature. It is worth noting, however, that one of the best oils for the enrichment of sterols among the existing oils on the market is chia seed oil. In comparison with the results of Kopeć et al., (2011), yogurt enriched with a $2 \%$ addition of chia seed oil contained more phytosterols in $100 \mathrm{~g}$ of oil than corn oil $(0.95 \mathrm{~g} \cdot 100$ $\mathrm{g}^{-1}$ of oil), sesame oil $\left(0.87 \mathrm{~g} \cdot 100 \mathrm{~g}^{-1}\right.$ of oil) or sunflower oil $\left(0.73 \mathrm{~g} \cdot 100 \mathrm{~g}^{-1}\right.$ of oil).

\section{7. $\mathrm{pH}$ changes of yogurt during storage}

Based on the $\mathrm{pH}$ results it was found that the $2 \%$ addition of chia seed oil did not affect the $\mathrm{pH}$ of the yogurt. This parameter slightly decreased during storage, especially during the first 14 days, in which it decreased by 0.2 in natural yogurt. During the next 14 days of storage only a 0.07 decrease in $\mathrm{pH}$ was reported (Table 7). A similar trend was observed in yogurt enriched with $2 \%$ chia seed oil, where after the first 14 days of storage the $\mathrm{pH}$ decreased by 0.17 and in the next 14 days by nearly 0.06 . Sady et al., (2007) also observed that the highest acidity of analyzed yogurt was observed in the first 14 days of production. A slight decrease in the $\mathrm{pH}$ value of the yogurt during refrigerated storage conditions is a well-known effect in many beverages fermented by lactic acid bacteria (Zareba and Ziarno, 2017). These changes should be explained by the biochemical activity of still living cells of lactic bacteria. As long as lactic bacteria cells remain biologically active or their enzymes are active, changes in the chemical composition of the product (including the concentration of hydrogen ions) can be observed.

\subsection{Sensory evaluation of yogurt samples}

On the day of production, natural yogurt was characterized by a high average score (above 4.8) of the following characteristics: gloss, lack of taste and odor of fat, structure uniformity and sweetness (Figure 2). Lower scores were obtained for the distinctive taste and aroma of yogurt and also color, texture and foreign flavor. It is worth noting that the acidity of yogurt was rated by the sensory analysts as high and this characteristic was evaluated as the lowest average score of 4.27. After 14 days of storage, the acceptability of gloss, taste and odor of fat increased. The texture of the product was improved, which was characterized by higher density and less whey content on the surface, which

TABLE 7. Acidity changes in natural and enriched yogurt during 28 days of storage $(n=3$, mean $\pm S D)$

\begin{tabular}{cccc}
\hline & \multicolumn{2}{c}{ Yogurt type } \\
\cline { 2 - 4 } & Storage days & Natural & Enriched with chia seed oil \\
\hline $\mathrm{pH}$ & 0 & $4.07 \pm 0.14^{\mathrm{a}}$ & $4.10 \pm 0.21^{\mathrm{a}}$ \\
& 14 & $3.87 \pm 0.20^{\mathrm{a}}$ & $3.93 \pm 0.04^{\mathrm{a}}$ \\
& 28 & $3.80 \pm 0.08^{\mathrm{a}}$ & $3.87 \pm 0.01^{\mathrm{a}}$ \\
\hline
\end{tabular}

a-c Different superscripts within a row show significant differences during storage $(\mathrm{P}<0.05)$ (according to one way ANOVA and Tukey) 


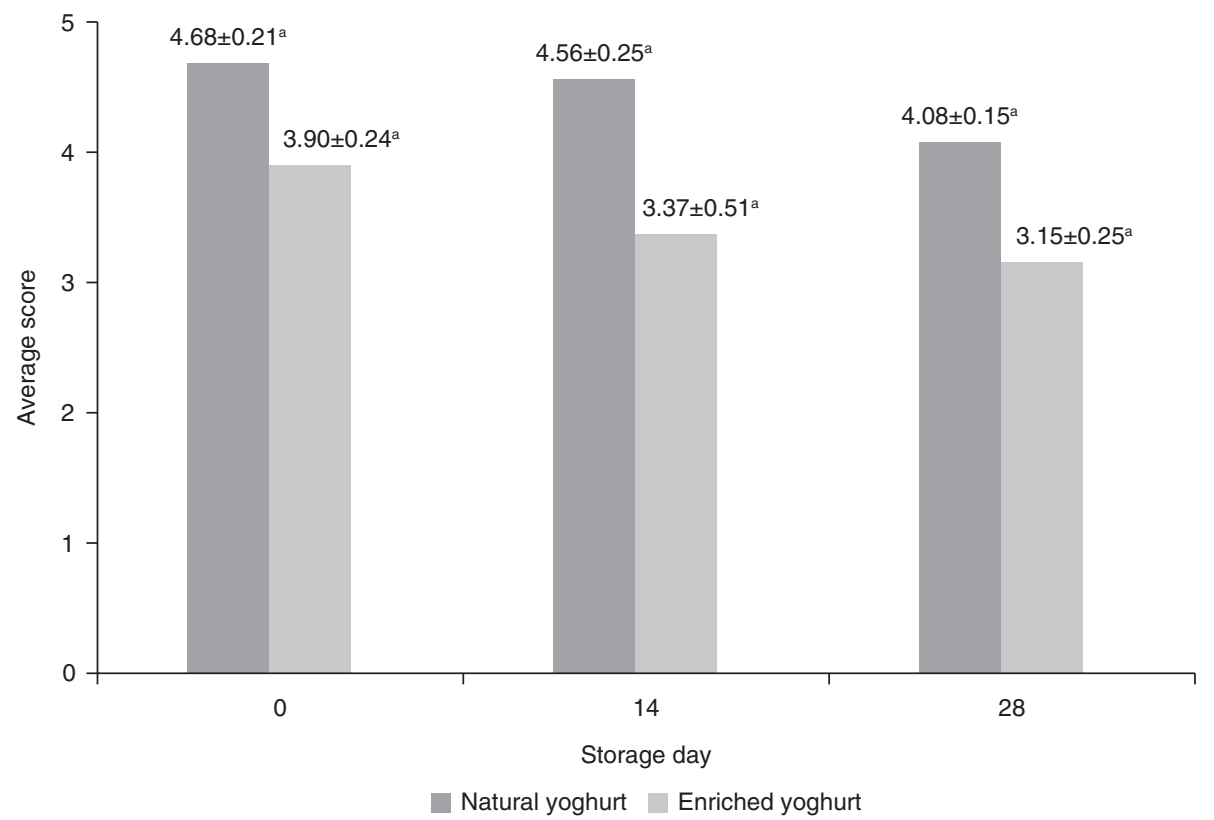

FIGURE 1. Changes in average ratings of natural yogurt and enriched yogurt during 14 and 28 days of storage ( $n=3$, mean \pm SD) a-c Different superscripts within a columns show significant differences after storage $(\mathrm{P}<0.05)$ (according to one way ANOVA and Tukey)

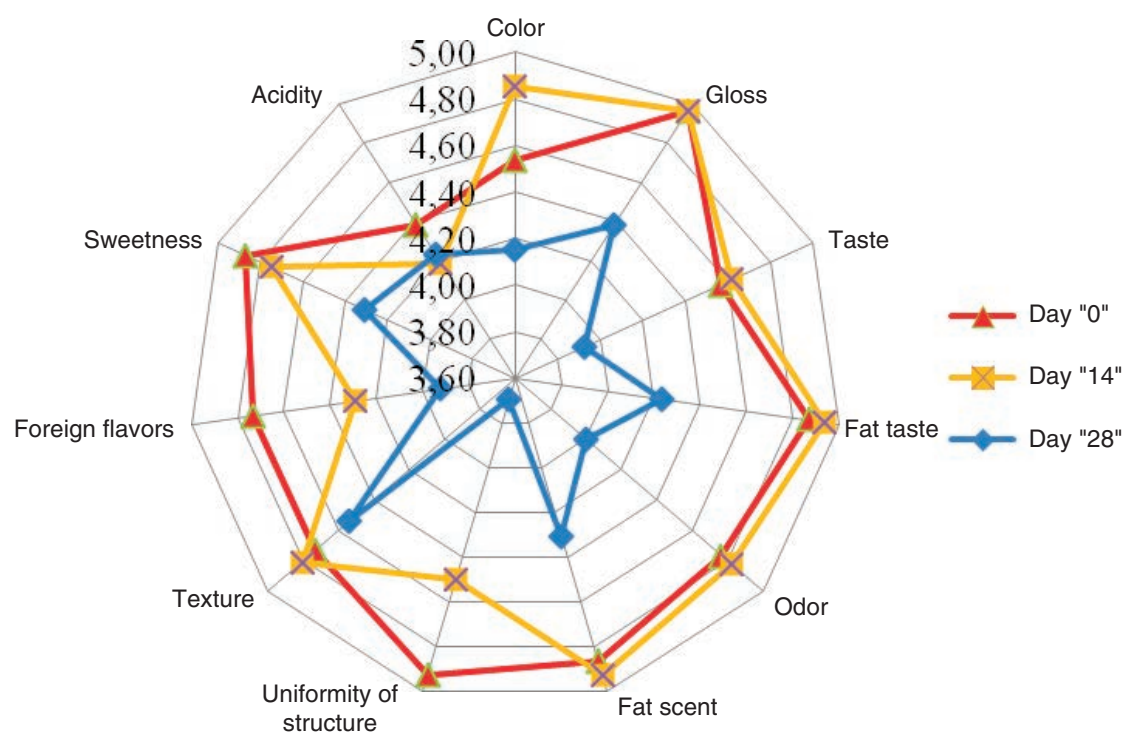

FIGURE 2. Changes of characteristics measured in natural yogurts after 14 and 28 days of storage

resulted in a higher average score for yogurt color, which became whiter for the analysts. After 14 days of storage, the score for sweetness and acidity of yogurt declined, and more foreign flavors were observed (Figure 2). After 28 day of storage of natural yogurt the scores for all characteristics were lowered. The lowest scores were given by the panelists to the uniformity of the structure because on the surface of the yogurt, yellow, opaque whey had formed (Figure 2). The analysts determined that foreign flavors were strongly felt, which were named as rancid fat, astringency, bitterness and aroma of cowshed. The longer the storage time, the acidity of the yogurt increased (which also confirms the yogurt $\mathrm{pH}$ measurement), so that sweetness was underestimated by the analysts.

The enriched yogurt was characterized by lower sensory acceptability compared to natural yogurt. The overall evaluation of the sensory characteristics of the enriched yogurt on production day showed that the product had no sensory features that prevented its consumption, and the average score was 


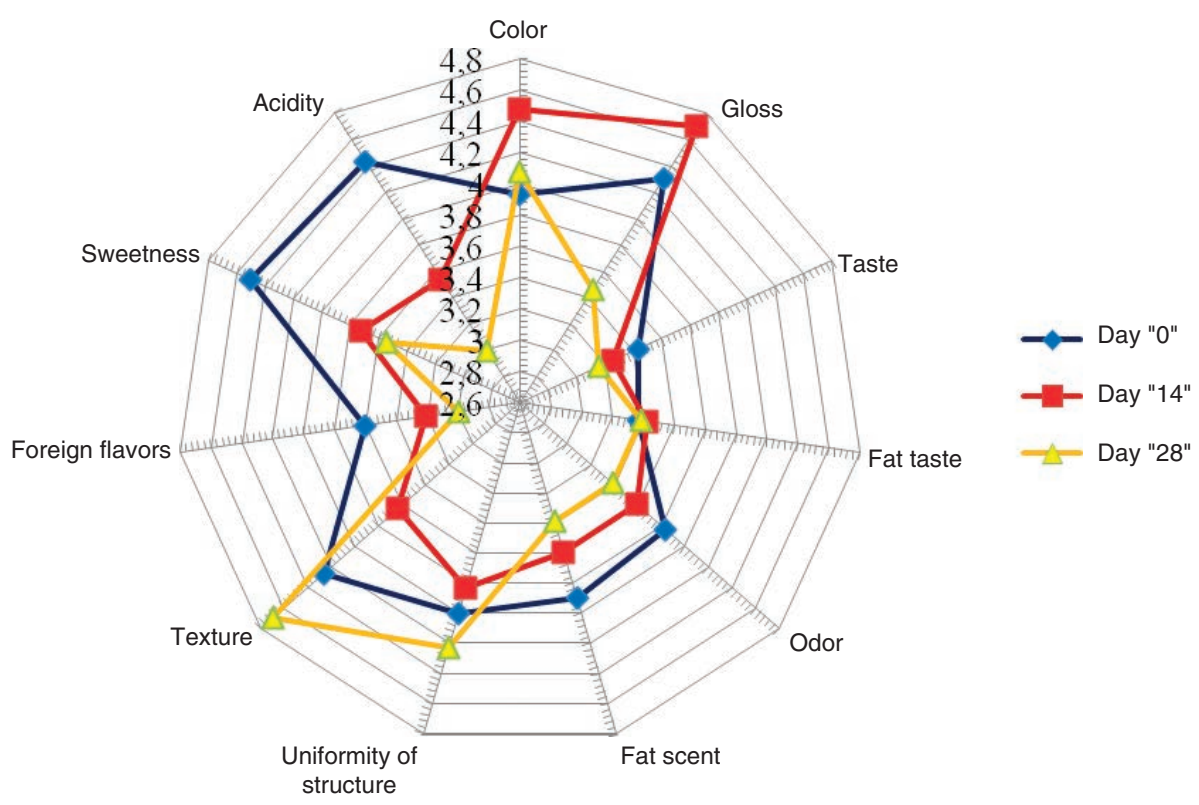

FIGURE 3. Changes in average scores of characteristics measured in enriched yogurts after 14 and 28 days of storage

3.9 (Figure 3). This assessment showed a downward trend, along with prolonged time of storage, it accounted for 3.37 after14 days of storage and was 3.37 and 3.15 after 28 days of storage. On production day 0 the sweetness of the yogurt enriched with chia seed oil was evaluated as high, while on the other hand, the acidity of the yogurt was low. The lowest scores were given to the taste and aroma typical for dairy products and the taste and aroma of fat. All of the listed features showed a declining trend for acceptability along with extended shelf life. The uniformity of the structure and texture after 14 days of storage were evaluated with lower scores than samples from the first day of production. Surprisingly, the same characteristics were evaluated with higher scores for the products after 28 days of storage. The testers noted that after 28 days' storage the products were clearly thicker, without the presence of whey on the surface, whereby the color was evaluated above (as a cleaner, whiter) than on the first day of production. The improvement in the structure and texture was probably due to the fact that the oil components had binding properties to the yogurt's water fraction. Phytosterols such as oryzanol and sitosterol can form fibrillar structures in an aqueous phase. Moreover, phytosterols have surface activity, which results in the migration of phytosterols to the oil from the water interface of the emulsion droplets. Some of the molecules can form crystalls in the water phase (Moschakis et al., 2017). On the other hand the flavor of cowshed, cod-liver oil and old fat was mentioned by the panelists (Figure 3).

Comparing the overall scores for natural and enriched yogurt (Figure 1), it was observed that natural yogurt was more acceptable to the analyzers, who just after production rated it an average of 4.68, and the enriched yogurt an average of 3.9. After 14 and 28 days of storage the acceptance of all the products was lower evaluated. Enriched yogurt had lower scores for fat taste and odor than natural yogurt. The testers found that foreign flavors derived from natural yogurt (like boiled milk or cowshed) were more strongly felt by the taste and odor of chia seed oil, by which the acceptability of this distinguishing characteristic was much lower. In both yogurts, the scores give to the sensation of sweetness and acidity decreased with prolonged storage time (as confirmed by the $\mathrm{pH}$ results). The opposite tendencies were observed for texture and uniformity of structure. Natural yogurt has a tendency to decline in scores for the texture and uniformity of the structure (it was delaminated, with a large amount of whey cream on the surface), and in the enriched yogurt the evaluation improved (yogurt was thicker with no whey found on its surface).

Similar observations were made by other authors in natural yogurt (Pikul and Wójtowski, 2008), who concluded that with the prolonged storage period, yogurt's overall desirability and taste and aroma deteriorate considerably. Sady et al., (2007) also observed that oil-enriched yogurt was less acceptable than natural yogurt without additives.

\subsection{Analysis of the presence of selected microorganisms in yogurt}

The number of lactobacilli on the first day of storage of natural yogurt was $6.3 \log \mathrm{CFU} \cdot \mathrm{g}^{-1}$, and in enriched yogurt it was $6.2 \log \mathrm{CFU} \cdot \mathrm{g}^{-1}$. For comparison, the Str. thermophilus population was at 
TABLE 8. Yogurt bacteria population in yogurt $\left(\log \mathrm{CFU} \cdot \mathrm{g}^{-1}\right)(\mathrm{n}=3$, mean $\pm \mathrm{SD})$

\begin{tabular}{lccc}
\hline & \multicolumn{2}{c}{ Storage days } \\
\cline { 2 - 4 } Yogurt bacteria & $\mathbf{0}$ & $\mathbf{1 4}$ & $\mathbf{2 8}$ \\
\hline & & Natural yogurt & $6.3 \pm 0.11^{\mathrm{a}}$ \\
Lb. delbrueckii subsp. bulgaricus & $6.3 \pm 0.09^{\mathrm{a}}$ & $6.1 \pm 0.18^{\mathrm{a}}$ & $9.0 \pm 0.1^{\mathrm{c}}$ \\
Str. thermophilus & $6.3 \pm 0.21^{\mathrm{a}}$ & $7.4 \pm 1.14^{\mathrm{b}}$ & $6.1 \pm 0.07^{\mathrm{a}}$ \\
& & Enriched yogurt & $6.0 \pm 0.16^{\mathrm{a}}$ \\
Lb. delbrueckii subsp. bulgaricus & $6.2 \pm 0.08^{\mathrm{a}}$ & $7.2 \pm 1.0^{\mathrm{b}}$ & $8.36^{\mathrm{c}}$ \\
Str. thermophilus & $6.1 \pm 0.23^{\mathrm{a}}$ & & \\
\hline
\end{tabular}

a-c Different superscripts within a row show significant differences during storage $(\mathrm{P}<0.05)$ (according to one way ANOVA and Tukey)

the same level. After 28 days of storage Str. thermophilus dominated over lactobacilli, with a content of $9.0 \log \mathrm{CFU} \cdot \mathrm{g}^{-1}$ in natural yogurt, and $8.8 \mathrm{log}$ $\mathrm{CFU} \cdot \mathrm{g}^{-1}$ in enriched yogurt (Table 8 ). Whereas the Lb. delbrueckii subsp. bulgaricus population did not change stastically significantly after 28 days of storage (6.3 log CFU.g ${ }^{-1}$ for natural yogurt, and $6.1 \mathrm{log}$ $\mathrm{CFU} \cdot \mathrm{g}^{-1}$ for the yogurt enriched with $2 \%$ chia seed oil). This is because the Lb. delbrueckii bulgaricus: Str. thermophilus proportion was at a 1:1 ratio at the beginning of the experiment, and some changes were observed during the storage period. Amoroso et al., (1988) reported that the optimal ratio between lactobacilli and streptococci in yogurt should range from 1:1 to $1: 2$. This phenomenon is related to the symbiosis of these two bacterial genera, the fermentation temperature used in the experiment as well as the increased acidity of fermented beverages during storage, even in refrigerated conditions (Sady et al., 2007).

\section{CONCLUSIONS}

The results from our study show that chia seed oil might be used as an additive to yogurt. The nutritional quality of enriched natural yogurt was shown to have been improved due to a high content of polyunsaturated fatty acids (mainly by linoleic and $\alpha$-linolenic acid) and phytosterols ( $2 \mathrm{~g}$ of phytosterol in $100 \mathrm{~g}$ of fat fraction). Moreover, during a 4-week storage period, the physical and sensory properties of enriched yogurt were not changed significantly compared to natural yogurt and the amount of total LAB was not reduced in the analyzed yogurts, which proved the high stability of the enriched products.

These results indicate that chia seed oil can be used by the food industry to enrich yogurt, considering the fact that the addition of chia seeds to fermented milk products is not permitted in EU. The use of chia seed oil can be seen as the good alternative to the chia seed addition. The results of our study may open new opportunities for the design of fermented products containing large amounts of phytosterols, which decrease cholesterol levels in human blood and lower the risk of cardiovascular diseases. Moreover, consumption of this kind of enriched yogurt may protect people from neurodegenerative diseases due to its high concentration of $\omega-3$ fatty acids.

\section{REFERENCES}

Agriculture and Agri-Food Canada -Report 2015, Market Access Secretariat Global Analysis Report, Dairy Products Western Europe January 2015, http://www.agr.gc.ca/ resources/prod/Internet-Internet/MISB-DGSIM/ATSSEA/PDF/6581-eng.pdf

Alvarez-Chavez LM, Valdivia-Lopez MDLA, Aburto-Juarez MDL, Tecante A. 2008. Chemical characterization of the lipid fraction of Mexican chia seed (Salvia hispanica L.). Int. J. Food Prop. 11, 687-697. https://doi. org/10.1080/10942910701622656

Amoroso MJ, Manca De Nadra MC, Oliver G. 1998. Glucose, galactose, fructose, lactose and sucrose utilisation by Lactobacillus bulgaricus and Streptococcus thermophilus isolated from commercial yogurt. Milchwissenschaft. 43, 626-629.

Ayerza R, Coates W. 2011. Protein content, oil content and fatty acid profiles as potential criteria to determine the origin of commercially grown chia (Salvia hispanica L.). Ind. Crops Prod. 34, 1366-1371. https://doi.org/10.1016/j. indcrop.2010.12.007

Buttriss J. 2003. YOGURT, Dietary Importance. Encyclopedia of Food Sciences and Nutrition (Second Edition), ed. Benjamin Caballero.

Cichosz G, Czeczot H. 2011. Oxidative stability of edible fats consequences to human health. Bromat. Chem. Toksykol. 1, 50-60. http://www.ptfarm.pl/pub/File/bromatologia_2011/1/br\%201_2011\%20s.\%20050-060.pdf

Coelho MS, Salas-Mellado MM. 2014. Chemical Characterization of Chia (Salvia hispanica L.) For use in food products. J. Food Nutr. Res. 2, 263-269. https://doi. org/10.12691/jfnr-2-5-9

Ding Y, Lin H-W, Lin Y-L, Yang D-J, Yu Y-S, Chen J-W, Wang S-Y, Chen Y-C. 2018. Nutritional composition in the chia seed and its processing properties on restructured hamlike products. J. Food Drug Anal. 26, 124-134. https://doi. org/10.1016/j.jfda.2016.12.012

EU website, https://ec.europa.eu/food/safety/novel_food/ authorisations/summary-ongoing-applicationsand-notifications_en

Fernandez I, Vidueiros SM, Ayerza R, Coates W, Pallaro A. 2008. Impact of chia (Salvia hispanica L.) on the immune system: preliminary study. Proc. Nutr. Soc. 67, Article E12.

Florence AC, Beal C, Silva RC, Bogsan CSB, Pilleggi ALOS, Gioielli LA, Oliveira MN. 2012. Fatty acid profile 
trans-octadecanoic, $\alpha$-linolenic and conjugated linoleic acid contents differing in certified organic and conventional probiotic fermented milks. Food Chem. 135, 22072214. https://doi.org/10.1016/j.foodchem.2012.07.026

Gahruie HH, Eskandari MH, Mesbahi G, Hanifpour HA. 2015. Scientific and technical aspects of yogurt fortification: A review. Food Sci. Human Wellness 4, 1-8. https:// doi.org/10.1016/j.fshw.2015.03.002

Gawrysiak-Witulska M, Rudzińska M, Wawrzyniak J, Siger A. 2012. The Effect of Temperature and Moisture Content of Stored Rapeseed on the Phytosterol Degradation Rate. JAOCS 89, 1673-1679. https://doi.org/10.1007/ s11746-012-2064-4

Grega T, Sady M, Pustowiak H. 2000. Poziom cholesterolu i kwasów tłuszczowych w różnych rodzajach mleka spożywczego. Zesz. Nauk. AR w Krakowie, Technologia Żywności. 12 (367), 85-90.

Kargulewicz A, Swora-Cwynar E, Marcinkowska E, Grzymisławski M. 2016. Chia seeds as a valuable food product of a balanced diet - its application in the prevention of metabolic diseases. Polish Nursing 1(59), 87-90.

Kaur N, Chugh V, Gupta AK. 2014. Essential fatty acids as functional components of foods-a review. J. Food Sci. Technol. 51, 2289-2303. https://doi.org/10.1007/s13197-012-0677-0

Kopeć A, Pysz M, Borczak B, Sikora E, Rosell CM, Collar C, Sikora M. 2011. Effects of sourdough and dietary fibers on the nutritional quality of breads produced by bakeoff technology. J. Cereal Sci. 54, 499-505. https://doi. org/10.1016/j.j.cs.2011.07.008

Kovacs A, Sulicsek R, Varga L, Szigeti J, Herpai Z. 2004. Relationship between cholesterol and fat contents of commercial dairy products. Acta Aliment. Hung. 233, 387-395. https://doi.org/10.1556/AAlim.33.2004.4.9

Lee H, Yoon H, Ji Y, Kim H, Lee J, Shin H, Holzapfel W. 2011. Functional properties of Lactobacillus strains isolated from kimchi. Int. J. Food Microbiol. 1, 155-161. https://doi. org/10.1016/j.ijfoodmicro.2010.12.003

Melgosa R, Benito-Román Ó, Sanz MT, Paz de E, Beltrán S. 2019. Omega-3 encapsulation by PGSS-drying and conventional drying methods. Particle characterization and oxidative stability. Food Chem. 270, 138-148. https://doi. org/10.1016/j.foodchem.2018.07.082

Moschakis T, Dergiade I, Lazaridou A, Biliaderis CG, Katsanidis E. 2017. Modulating the physical state and functionality of phytosterols by emulsification and organogel formation: Application in a model yogurt system. J. Funct. Foods 33, 386-395. https://doi.org/10.1016/j.jff.2017.04.007

Nadeem M, Imran M, Taj I, Ajmal M, Junaid M. 2017. Omega-3 fatty acids, phenolic compounds and antioxidant characteristics of chia oil supplemented margarine. Lipids Health Dis. 16, 102. https://doi. org/10.1186/s12944-017-0490-x

Nieminen V, Laakso P, Kuusisto P, Niemelä J, Laitinen K. 2016. Plant stanol content remains stable during storage of cholesterollowering functional foods. Food Chem. 196, 13251330. https://doi.org/10.1016/j.foodchem.2015.10.059

Paszczyk B, Zegarska Z, Rafałowski R, Borejszo Z. 2006. Annual changes in the content of unsaturated fatty acids with 18 carbon atoms, including cis9trans11 C18:2 (CLA) acid, in milk fat. Pol. J. Food Nutr. Sci. 4, 15-56.

Pikul L, Wójtowski J. 2008. Fat and cholesterol content and fatty acid composition of mare's colostrums and milk during five lactation months. Livest Sci. 113, 285-290. https://doi. org/10.1016/j.livsci.2007.06.005

Rahman J, Camargo de AC, Shahidi F. 2017. Phenolic and polyphenolic profiles of chia seeds and their in vitro biological activities. J. Funct. Foods 35, 622-634. https://doi. org/10.1016/j.jff.2017.06.044

Rossi AS, Oliva ME, Ferreira MR. 2013. Dietary chia seed induced changes in hepatic transcription factors and their target lipogenic and oxidative enyme acitvities in dyslipidaemic insulin-resistant rats. Br. J. Nutr. 109, $1617-1627$.

Rudzińska M, Przybylski R, Wąsowicz E. 2014. Degradation of phytosterols during storage of enriched margarines. Food Chem. 142, 294-298. https://doi.org/10.1016/j. foodchem.2013.07.041

Sady M, Domagała J, Grega T, Kalicka D. 2007. Effect of the storing period on micro-flora in yogurts containing amaranth seeds and oat grains added. Zywn-Nauk Technol. Ja. 6 (55), 242-250.

Segura-Campos MR, Ciau-Solís N, Rosado-Rubio G, ChelGuerrero L, Betancour-Ancona D. 2014. Physicochemical characterization of chia (Salvia hispanica) seed oil from Yucatán, México. J. Agric. Sci. 5, 220-226. https://doi. org/10.4236/as.2014.53025

Silva da BP, Anunciação PC, Silva da Matyelka JC, Lucia CMD, Martino HSD, Pinheiro-Sant'Ana HM. 2017. Chemical composition of Brazilian chia seeds grown in different places. Food Chem. 221, 1709-1716. https://doi. org/10.1016/j.foodchem.2016.10.115

Talpur FN, Bhanger MI, Memon NN. 2008. Fatty acid composition with emphasis on conjugated linoleic acid (CLA) and cholesterol content of Pakistan dairy products. Pol. J. Food Nutr. Sci. 58 (3), 313-320.

Zareba D, Ziarno M. 2017. The viability of yogurt bacteria in selected plant beverages. Zesz. Probl. Post. Nauk Roln. 591, 87-96. https://doi.org/10.22630/ZPPNR.2017.591.46 